Apart from these symposia, Prof. Pauling gave two separate lectures-one on a new approach to the problem of ferromagnetism and the other on the connexion between various blood-cell diseases and structural changes in the hæmoglobin molecule. Prof. Mark also lectured, with interesting demonstrations, on new types of synthetic polymers.

The Memorial Convocation ended in December with series of lectures by Sir Robert Robinson on "Structural Relations in Natural Compounds"; these constitute the first set of Weizmann Memorial Lectures, which, it is intended, will become an annual event.

\section{EXPERIMENTAL BIOLOGY AT THE WEIZMANN INSTITUTE OF SCIENCE, REHOVOTH, ISRAEL}

$\mathrm{T}$

HE official opening of the Isaac Wolfson Building for Experimental Biology on November 3 represents the completion of a further stage in the development and expansion programme of the Weizmann Institute of Science in Rehovoth.

The Weizmann Institute of Science, which grew out of the former Daniel Sieff Research Institute of Organic Chemistry and Microbiology, began its first stage of expansion in 1948, with the creation of new departments for applied mathematics, optics, isotope research, biophysics and high-polymer research. At that time, plans were already being made for a further extension towards the ultimate creation of an Institute of Biological and Medical Sciences, of which the present Wolfson Building is a first stage, to accommodate the Department of Experimental Biology.

The new building is an attractive, four-story structure, of about 500 square yards per floor. It is air-conditioned, with a lift, broad corridors and other amenities suitable for animal work. It includes ten laboratories, eight animal rooms, three rooms for cleaning and sterilizing of cages, an operating unit, a library, a seminar room, a photographic unit, and

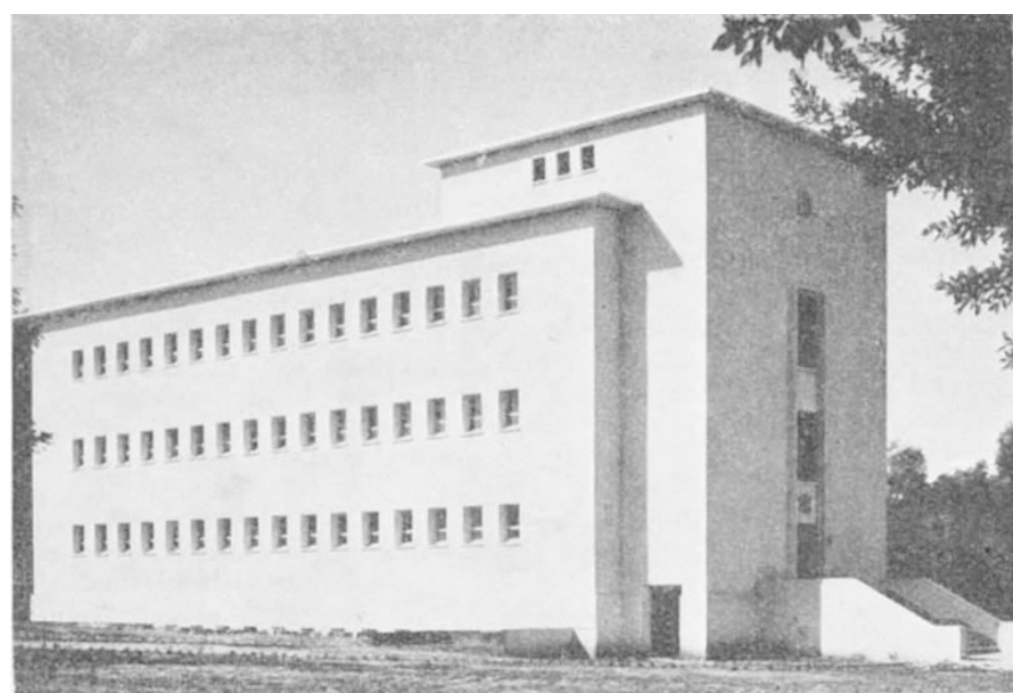
Isaac Wolfson Building, Weizmann Institute of Science, Rehovoth. Copyright Schleissner
Rechovo storage rooms. The internal construction is of $\mathbf{a}$ somewhat flexible design, for easy convertibility from laboratory to animal room, etc.

The Department of Experimental Biology is under the direction of Dr. I. Berenblum, formerly of the Sir William Dunn School of Pathology, University of Oxford. The major field of research in the Department is on cancer, with special emphasis on the mechanism of carcinogenesis. Included in the Department are separate units on endocrinology and cellular genetics ; it is hoped to include, in time, further units, for example, on pharmacology, experimental embryology, and basic nutritional research. The experimental animals, including several genetically inbred strains of mice, as well as rats, rabbits, guinea pigs and hamsters, are all bred on the premises, and additional facilities are available close by for outdoor breeding of the larger animals, with suitable runways, etc.

The Weizmann Institute of Science is, at the moment, engaged in planning a post-doctoral school, towards which the new developments in biological sciences will have much to contribute.

\section{EFFECT OF FLOODS ON THE OYSTER GROUNDS OF EASTERN BRITAIN}

\section{By G. DUNCAN WAUGH}

Fisheries Laboratory, Burnham-on-Crouch, Essex

A LL the oyster-producing grounds of the east coast of Britain were within the area affected by the floods of January 1953, and in many cases the damage done was considerable. In Essex, where the major losses occurred, oyster cultivation is carried on in the estuaries of the Rivers Colne, Blackwater, Crouch and Roach, and in the numerous creeks which enter these rivers. Many of these creeks are in reality embanked inlets in the marshes. Where the banks were broken, immediate and serious damage occurred on the adjacent oyster beds.

There were two main causes of loss: first, the burying of the oysters on the creek bottoms under debris from the land, and, secondly, the choking of the oysters in the rivers and creeks by the great quantities of silt present in suspension in the water. Damage of the first type usually occurred on oyster grounds which adjoined major breaches in the sea wall; for example, a big breach was made in the wall above Old Hall Marshes, near West Mersea, on the north side of the River Blackwater, and the oyster grounds in the upper part adjoining Tollesbury Fleet suffered severely. Surveys made soon after the floods showed that there was a thick layer of debris consisting of mud, turves, stalks and leaves of Spartina townsendii, etc., covering the oyster beds. A great deal of this material was putrefying. The work involved 